\title{
Study of the ravine-gully system of the city of Dnipro with the aim of returning them territories to the urban infrastructure
}

\author{
Kristina Zmiievska ${ }^{1, *}$, and Artur Zmiievskyi ${ }^{2}$ \\ ${ }^{1}$ Institute of Geotechnical Mechanics named by N. Poljakov of National Academy of Sciences of \\ Ukraine, 49005, Dnipro, Simferopolska Str., 2a, Ukraine \\ ${ }^{2}$ LLC “Epiroc Ukraine”, 04073, Kyiv, Stepana Bandery Ave., 9, Ukraine
}

\begin{abstract}
The article provides an analysis of the state of individual fragments of a ravine-gully system in the right-bank part of the city of Dnepr and its impact on the urban infrastructure. Examples of the successful use and construction of ravines with buildings and structures are considered. According to the results of the survey by the method of the natural impulse electromagnetic field of the Earth, a map-scheme of the flux density of the natural impulse electromagnetic field of the Earth was constructed in the area adjacent to the Monument of Glory, showing the presence of a previously covered ravine. The deformation processes that are observed on the eastern side of the Monastyrska gully are analyzed. Methods for strengthening landslide-prone slopes are considered.
\end{abstract}

\section{Introduction}

Currently, in the conditions of rapid urbanization of the territories of the city of Dnipro, various negative geo-ecological processes are actively manifested, which are progressing and negatively affecting the normal functioning of the city's systems. One of the most dangerous geo-ecological problems for an urban area are landslide processes and underflooding. The main reasons that stimulate the activation of these processes are:

- the influence of the fault-block system of the Serednoprydniprovskyi megablock;

- groundwater level rise;

- poor drainage areas;

- pressure of residential, industrial and transport systems and structures on the soil massif;

- construction residential and industrial buildings and structures without taking into account the slopes of geomorphological structures (terraces of the Dnipro river, gullies) and, accordingly, prevent the natural flow of surface and groundwater;

- gusts of water-bearing communications, etc.

All these negative factors contribute to the development of landslide processes, as well as the active growth of the ravine-gully system, which leads to the removal from the

${ }^{*}$ Corresponding author: zmievskaja@gmail.com 
economic turnover of valuable land for the city, mainly located in the central regions.

Within the limits of the right-bank part of the city of Dnipro, there are about 15 gullies and more than 20 ravines, which are constantly developing. Their average depth is $30-40 \mathrm{~m}$, they occupy about 5 thousand hectares, which is more than $25 \%$ of the territory under consideration. As a rule, gullies and ravines, especially the central part of the city, are intensively built up with one-storey, multi-storey and civil structures.

Gullies and ravines are natural drainage systems for both sediment drainage and leaks from water-carrying communications. Spontaneous landfills and uncontrolled low-rise buildings retain water, which causes numerous minor ground collapses and landslides. Among the most landslide-prone areas are the slopes of the Tunelna, Dovha, Yevpatoriiska, Diivska, Aptekarska, Zustrichna gullies. Most of the landslides were caused by human activities and a small part due to natural factors.

In this connection, the aim of the work is to study the ravine-gully system of the city, determine the degree of development of landslide-prone phenomena and identify the possibility of returning the territories of ravines and gullies into exploitation.

\section{Methods}

The study of the ravine-gully system of the city of Dnipro was carried out by means of reconnaissance studies, during which a description of the sides of the gullies and ravines was made, examples were given - the degree of their development, the presence of a drainage system, the prospects of their use.

In the accessible parts of ravines and gullies, the operational geophysical expressmethod for observing the natural impulse electromagnetic field of the Earth (NIEMFE) was used to assess the landslide risk of the slope with a radio-wave indicator of a stress-strain state of rocks (RWISSS AXI 2.026.001) [1]. The observation data of the NIEMFE were processed using a personal computer, then they were used to construct a map-scheme of the density of the NIEMFE flow. Deformation processes associated with tectonic disturbances were distinguished using the previously developed method [2].

\section{Results and discussion}

It is known that the ravines and gullies are laid on the deep faults. For example, sections of river valleys and a gully system, which are straightforward, are located most often in agreement with the strike of one of the fracture systems.

The following fault systems are developed on the territory of the right-bank part of the city of Dnipro, which is a fragment of the Srednepridneprovsky megablock (Fig. 1): $0^{\circ}$ $360^{\circ}, 12^{\circ}, 17^{\circ}$ and $290^{\circ}, 25^{\circ}, 30^{\circ}$ and $300^{\circ}, 35^{\circ}$ and $305^{\circ}, 40^{\circ}-45^{\circ}$ and $310-315^{\circ}, 50^{\circ}$ and $320^{\circ}, 85^{\circ}-90^{\circ}\left(270^{\circ}\right), 330^{\circ}-335^{\circ}, 340^{\circ}, 350^{\circ}[3]$.

Examples of the use of a ravine-gully system in the central part of the city are given.

A fragment of Yavornytskoho Avenue from Haharina Avenue and up to the Glory Monument is a ravine which filled in the 1960's. Its thalweg depth reached $30 \mathrm{~m}$. The length was about $600 \mathrm{~m}$. Its negative impact is seen on the boulevard, in the area of the Glory Monument in the form of cracks on the parapet, asphalt, sliding steps in the direction of the thalweg of the ravine, destruction of the retaining wall, the development of subsidence of the base of the monument (Fig. 2 a, b, c).

To assess the deformation processes occurring in the area of the Glory Monument, observations were made of the NIEMFE on the site from Haharina Avenue to the railway line (Prospektna Station). The location of the observation profiles is shown in Figure 3.

Observations of NIEMFE were carried out in accordance with the developed and 
protected patent. [4], on 5 profiles which attached to the reference coordinate points.

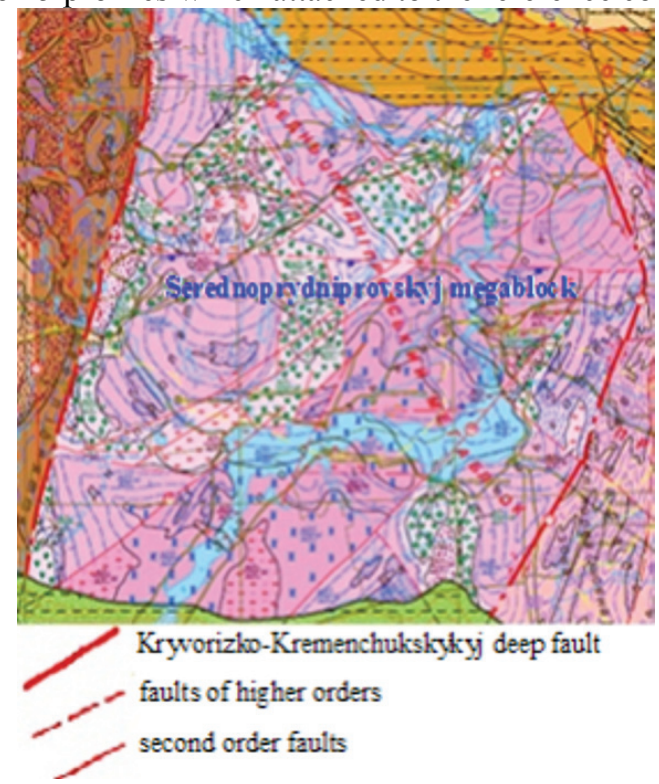

Fig. 1. Scheme of the tectonic structure of the Srednepridneprovsky megablock of the Ukrainian shield.

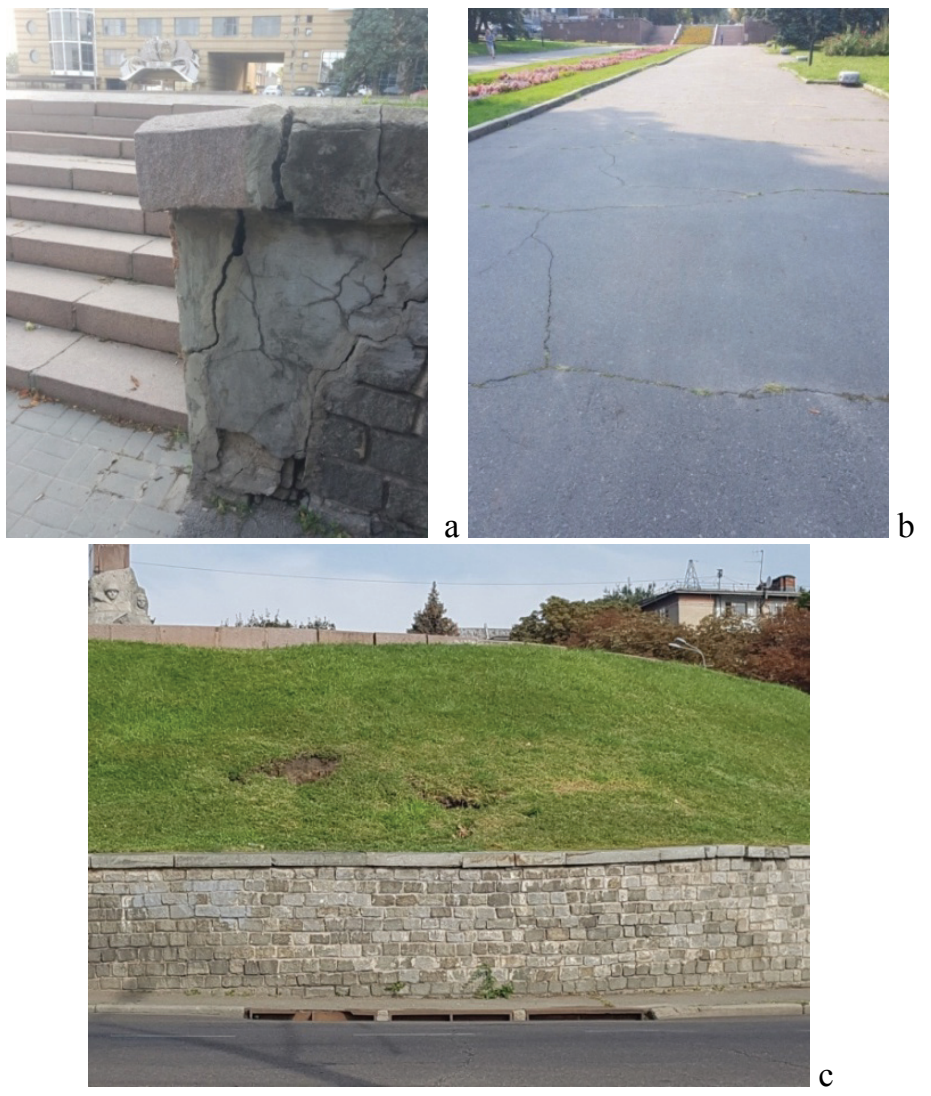

Fig. 2 a, b, c. Traces of parapet deformations in the area of the Glory Monument. 
Flow density is measured in c.u. (conditional units - number of impulses per unit time). Observations were made at 55 points. The distance between the observation points was $10 \mathrm{~m}$.

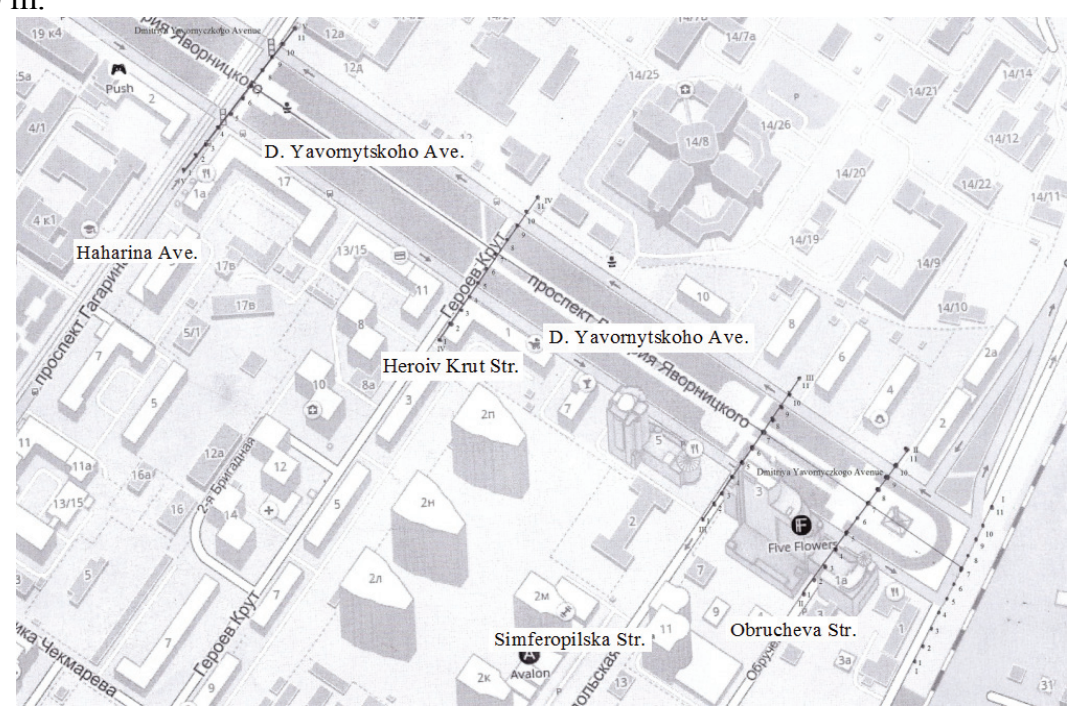

Fig. 3. Position of points and observation profiles of NIEMFE.

According to the observations, map-scheme of the NIEMFE flux was constructed (Fig. 4).

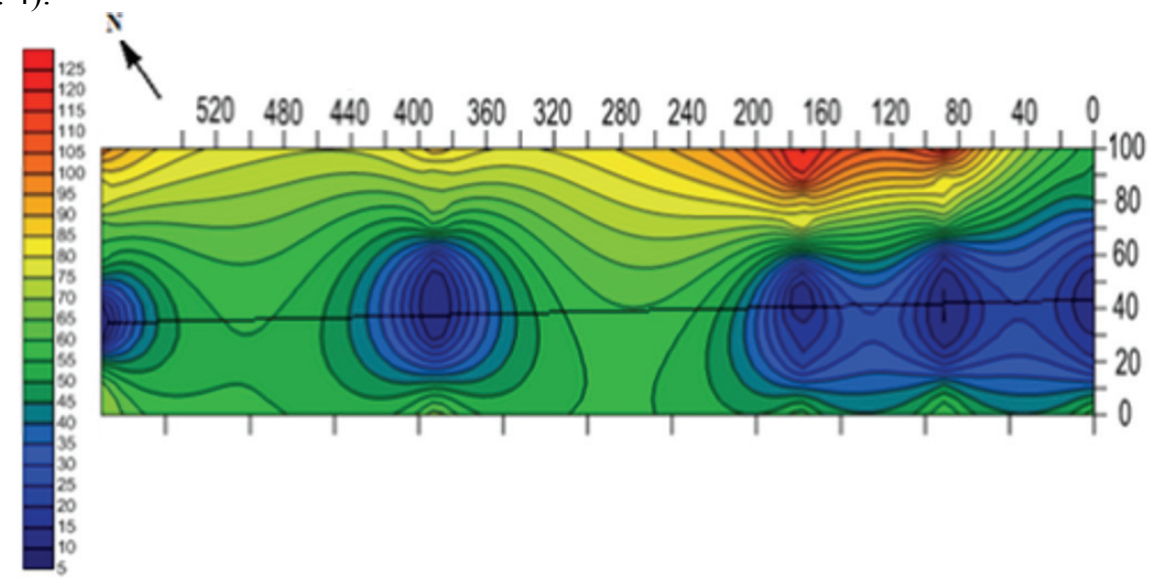

Fig. 4. Map-scheme of NIEMFE flux density site in the area of the monument of Glory: of flux density of NIEMFE, c.u.; $\square$ - axis of the selected ravine structure.

The flux density of NIEMFE at the study site varies from 1 to 125 c.u. When considering the resulting map-scheme, the attention is drawn to the clearly expressed linearity of the zone of minimum values (less than $35 \mathrm{cu}$ ), the axis of which has a strike azimuth of $310-315^{\circ}$. This direction is one of the main azimuths of the development of faults within the Srednepridneprovsky megablock. Attention is drawn to the zones of minimum values of NIEMFE, which coincide with the zones of the deformations described above. The presence of a sewer, located at the intersection of Heroiv Krut Str. and Yavornytskoho Ave. (profile IV) is reflected by a zone of low values of the density of the stream of NIEMFE - less than 35 c.u. (picket 380 along the $\mathrm{X}$ axis), is shown in Figure 4. 
Within the zones of low values of the NIEMFE flux density, intense destruction of the asphalt pavement, parapets, retaining walls, tiled pavements of the monument, sliding of steps and formation of saucers of subsidence of the Glory monument base are observed (Fig. 2 a, b, c).

Examples of the successful experience of using ravines in the urban infrastructure can be the following: a ravine, on the boards of which there are two blocks of the "Rassvet" Hotel, along the thalweg of which the passage to I. Akinfiieva (Fuchika) Str. is laid. Its dimensions are: thalweg length about $260 \mathrm{~m}$, width about $15-17 \mathrm{~m}$. The strike azimuth is about $85-90^{\circ}$ (Fig. 5).

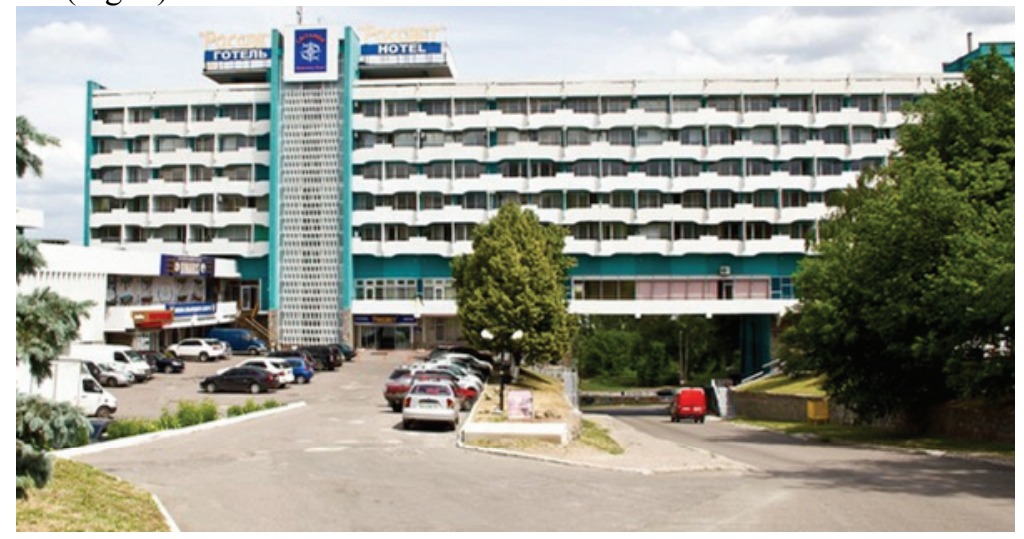

Fig. 5. An example of successful construction of a ravine on I. Akinfiieva street.

In its immediate vicinity is a beam passing through the 6th Strilkovoi Dyvizii str., on the bottom of which the stadium of the sports society "Slavutych" is equipped (Fig. 6 a, b). Its dimensions are: thalweg length about $260 \mathrm{~m}$, width about $115 \mathrm{~m}$. The strike azimuth is about $40-45^{\circ}$.
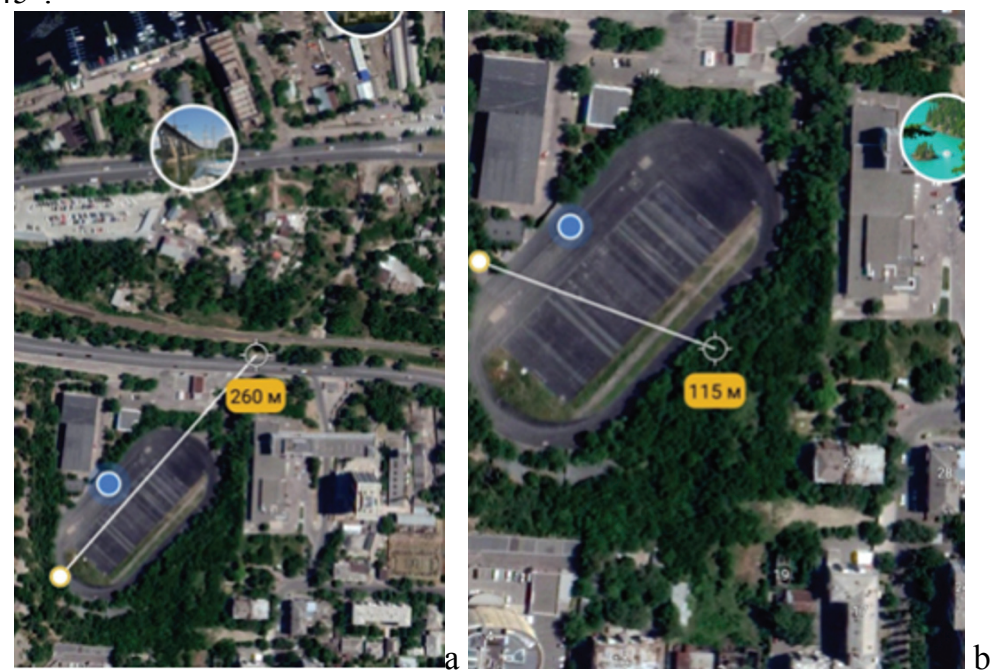

Fig. 6 a, b. Gully bottom construction along the 6th Strilkovoi Divizii str. with sports facilities of the "Slavutych" sports complex.

One of the most built-up and problematic gullies in the city is Monastyrska (Rybalska). The length of the beam on the thalweg, taking into account the lightened part about $500 \mathrm{~m}$. Gullies width about $385 \mathrm{~m}$. Depth to thalweg about $40-60 \mathrm{~m}$. The strike azimuth is $15-20^{\circ}$. A drain water collector with a diameter of about $1200 \mathrm{~mm}$ is laid along the bottom of the 
gully. Also there are numerous outlets of groundwater on the surface, forming waterways, sometimes swamped. Along the northeastern side of the gully are located Nakhimova str. and Havrylenka str., as well as buildings related to the O. Polia ave., schools, garages, stone fences. The buildings of this side of the gully have a high number of floors 5-14 floors. On the Havrylenka str., Nakhimova str., and O. Polia Ave. laid the rainfall system. On the north-west side of the gully are located Kholodnoyarska str, Listovyi lane, "Meteor" stadium, garages. Buildings, mainly low-rise. The most pronounced deformations appear on the buildings of the north-east side of the gully: Havrylenka str., 10 (Fig. 7 a), O. Polia Ave., 92 A (Fig. 7 b) and Nakhimova str., 90 (Fig. 7 c), which are currently decommissioned.
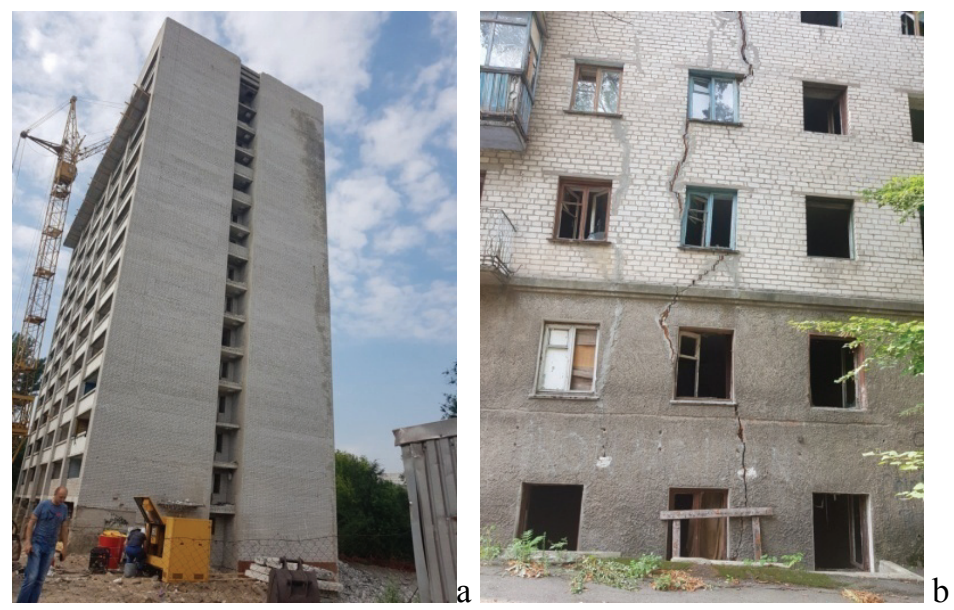

Fig. 7 a, b. Deformations of buildings along the eastern side of the Monastirskyi gully.

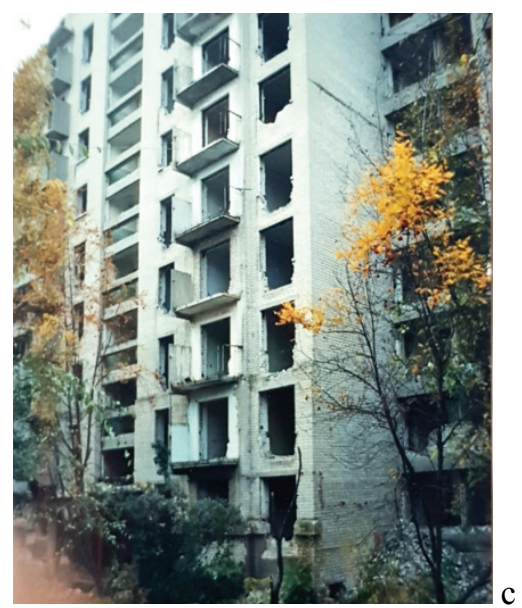

Fig. 7 c. Deformations of buildings along the eastern side of the Monastirskyi gully.

In 1996 and 2004 on the eastern side of the gully, observations of the NIEMFE were carried out [5].

According to the results of observations, zoning of the territory was carried out with the purpose of identifying tectonic zones along which landslide stages are formed. The slope profile has been used to plot graphs of the NIEMFE flux density, is shown in Figure 8.

On the graphs can be identified zones of development of deformation processes:

- the zone of no deformations according to the observations of NIEMFE in 1996 - 
according to the field level of 45 c.u., according to the observations in 2004: 40-45 c.u.;

- zones of active deformations - according to the field level in 1996: 45-30 c.u. on the field level in 2004: 44-35 c.u.;

- zone of emergency deformations - according to the level of the field in 1996: 30-3 c.u.; by the level of 2004: 35-10 c.u.;

According to the observation of the NIEMFE, there is a discharge area - in the area of school number 75. Below the discharge area, there is a gradual increase in stresses, in the area of the building on Havrylenka str., 10 (Fig. 8).

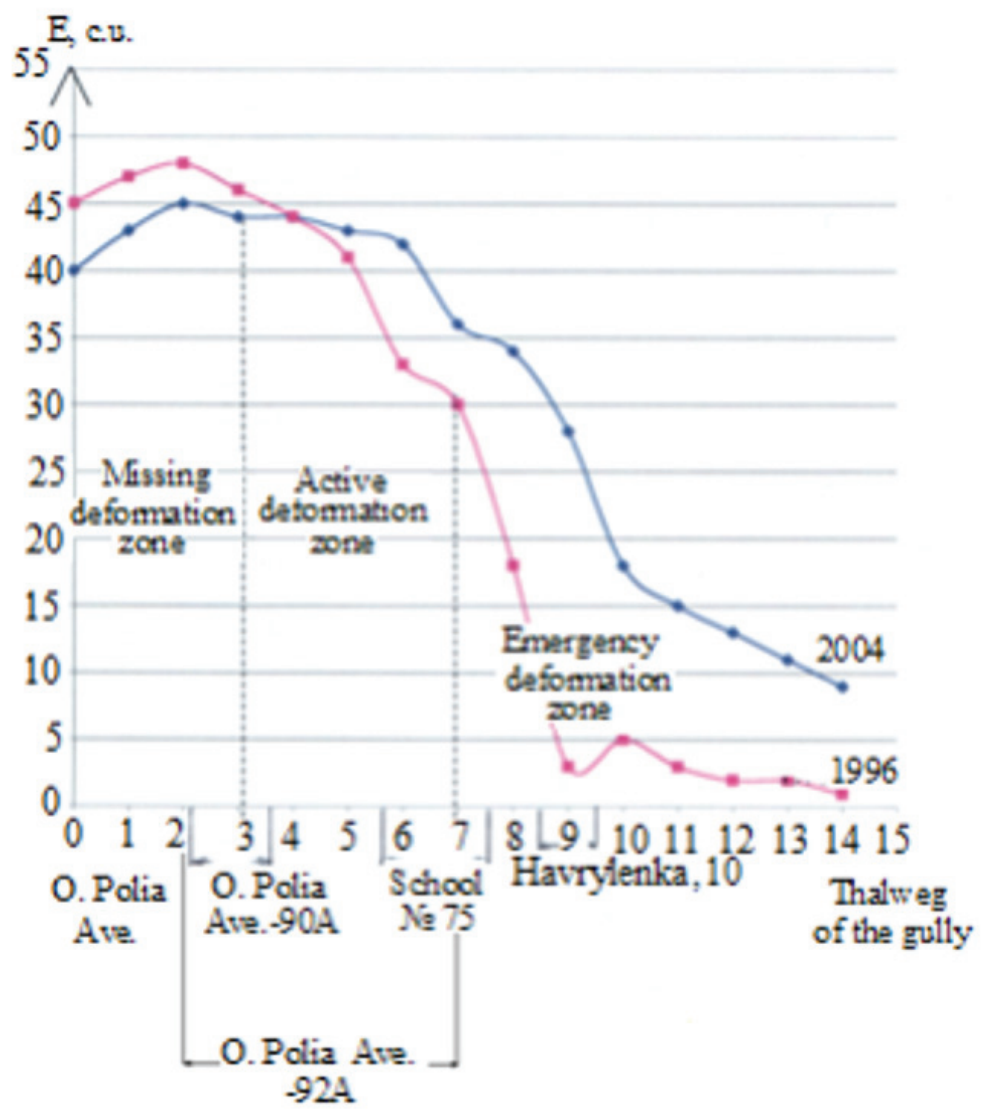

Fig. 8. Observation data of NIEMFE profile on the Havrylenka str. from O. Polia Ave. to thalweg Monastyrska gully in 1996 and 2004 [5].

The given examples of both the successful use of ravines and gullies, as well as the consequences of their destructive features, make the task of strengthening landslide-prone slopes for their further use relevant. One option is the methods developed by Epiroc, which is represented by LLC "Epiroc Ukraine".

The developed method allows to carry out drilling and sampling in difficult engineering and geological conditions and to create reinforcing retaining walls based on drilling data. At the same time, the basis of the method is core sampling by the Geobor S system (geotechnical core drilling) (Fig. 9) and its analysis in laboratory conditions [6]. The scope of the system - loose rocks, rocks of low and medium hardness.

In addition to the method described above, it is possible to install micropiles in the form of self-drilling anchors with the MAI SDA system (Fig. 10). This method is used for the following engineering and geological tasks: 
- strengthening of unstable rocks (soil);

- construction of foundations using micropiles;

- construction of tunnels [7].

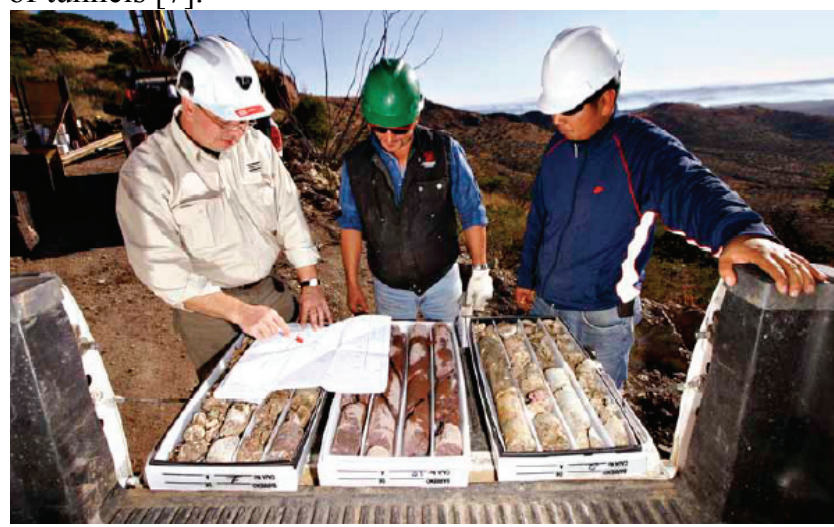

Fig. 9. Core sampling system GEOBOR S.

In geotechnical engineering, Soil and Rock Nails are used to stabilize natural or artificial slopes or to support structures e.g. retaining walls. In order to further stabilize the surface of the slope or rock, various support systems e.g. flexible reinforcing meshes or geotextiles may be installed that are held in place by the head plates of the nails. In underground applications, Soil and Rock Nails are predominantly used for fore poling, spiling, face bolting and radial bolting. The diameter of these anchors can be from $25 \mathrm{~mm}$ to $111 \mathrm{~mm}$, with a maximum load of 200 to $3650 \mathrm{kN}$.

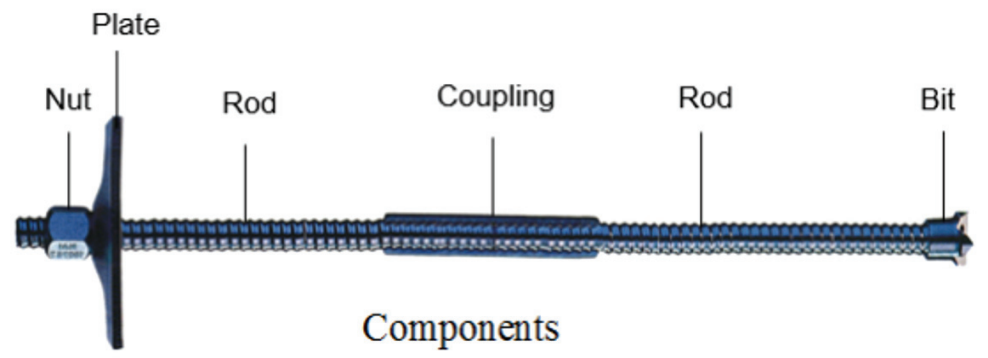

Fig. 10. Anchor MAI SDA.

Self Drilling Micropiles are typically installed via simultaneous drilling and grouting using cement grout as the flushing medium. Particularly in cohesion less or unstable ground conditions e.g. sand, clay or gravel, this is the fastest and most efficient installation method for micropile systems. Compared to other methods, smaller drilling equipment can be used. Thus Self Drilling Micropiles are ideally suited for projects with limited access, confined spaces or low headroom conditions (Fig. $11 \mathrm{a}, \mathrm{b}$ ).
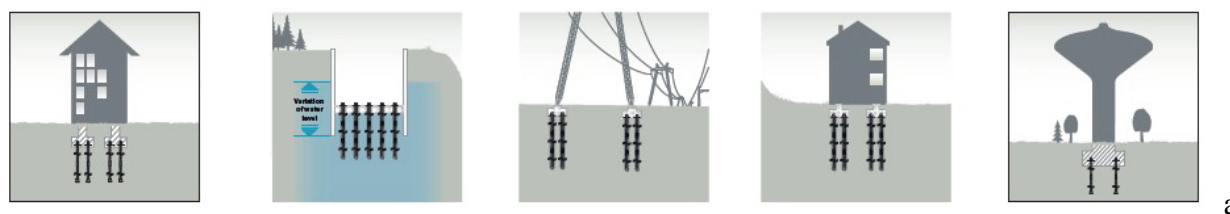

Fig. 11 a. The main areas of application of Self Drilling Micropiles. 

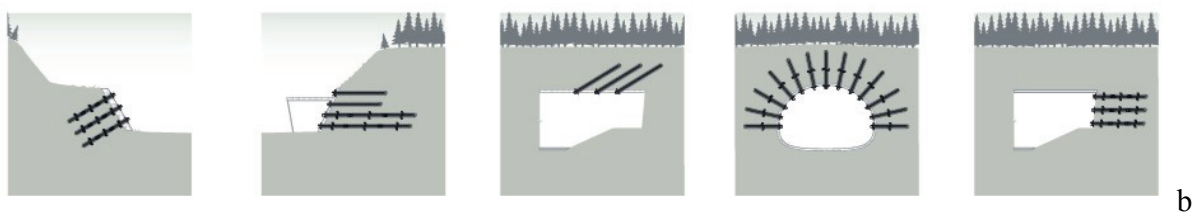

Fig. 11 b. The main areas of application of Self Drilling Micropiles.

Symmetrix simultaneous drilling system. It is used for the construction of wells in loose, unstable rocks with a diameter of $114 \mathrm{~mm}$ to $1219 \mathrm{~mm}$. This type of drilling operations provides for the construction of piles and allows drilling without difficulty in loose rocks, loose rocks with fragments of hard rocks, which makes it possible to begin construction of piles in loose, unstable rocks and complete the construction of a well in a rocky massif by drilling it into necessary interval. The described method compares favorably with the brown-injection method in that the brown-injection method is not able to qualitatively penetrate the pile into the rock base, since the screw drilling method is designed to destroy only soft rocks (Fig. 12 a, b). Symmetrix simultaneous drilling system is widely used in the countries of Europe in mountainous, coastal areas to strengthen the slopes and foundations of various types of structures [8].

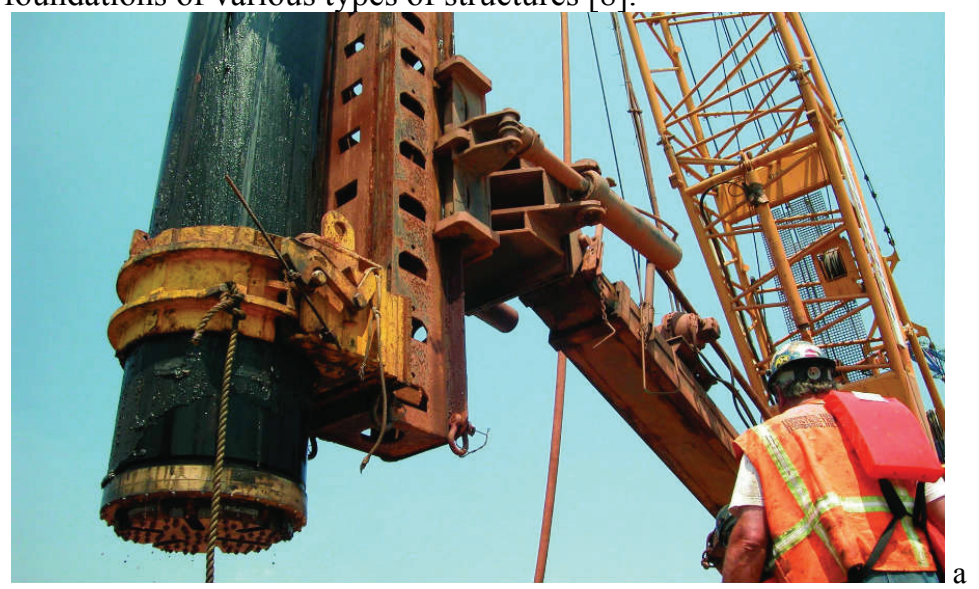

Fig. 12. Start of drilling for a pile of $1016 \mathrm{~mm}$ system Symmetrix.

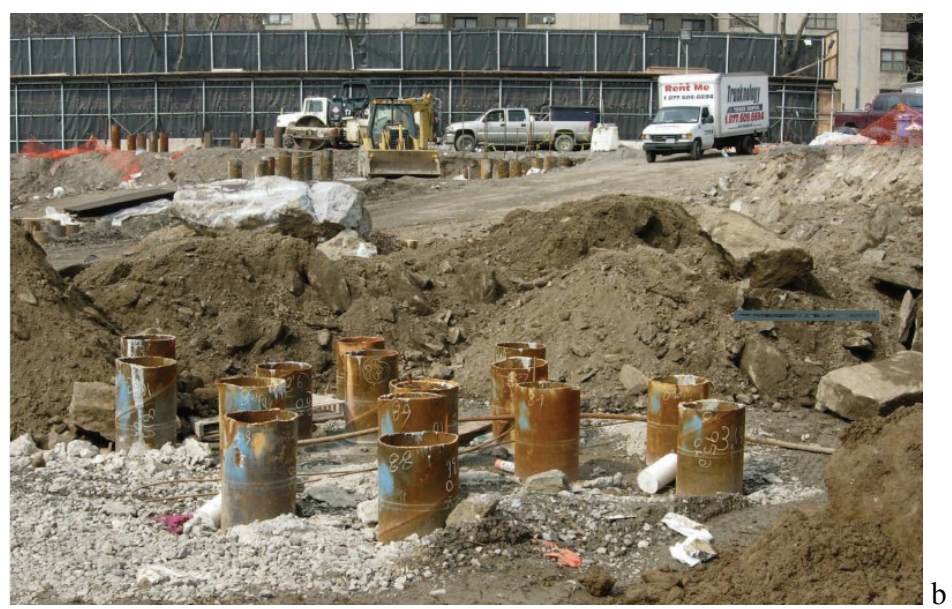

Fig. 12. End of drilling for a pile of $1016 \mathrm{~mm}$ system Symmetrix. 
Pile wall technology. This technology is used for construction of: retaining walls for temporary and permanent structures; combined load-bearing walls and supporting structures; combined support and supporting structures of the foundation in bridges; construction pits, basements, under intersections, embankment walls, etc (Fig. 13, 14).
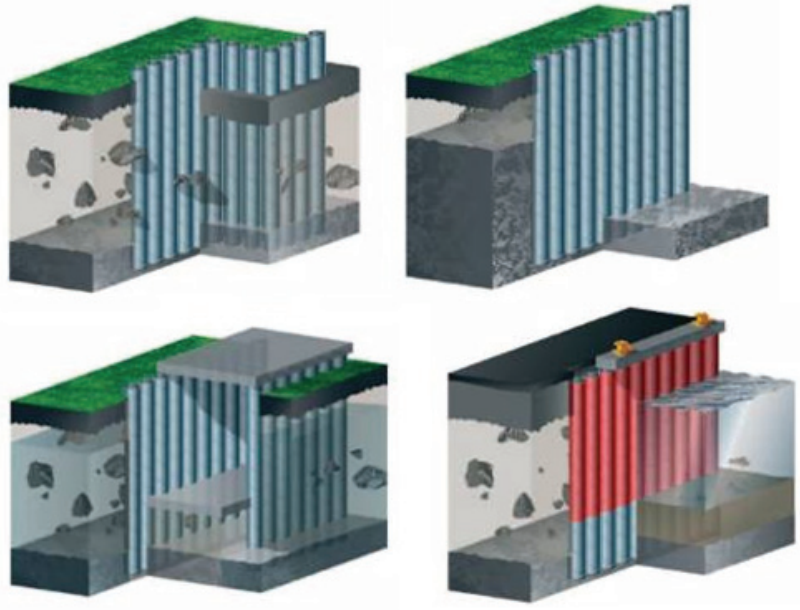

Fig. 13. Various forms of drilling casing rods.

During drilling pile wall technology, the pipe bodies are fixed to each other with the help of a blocking element (Fig. 14).

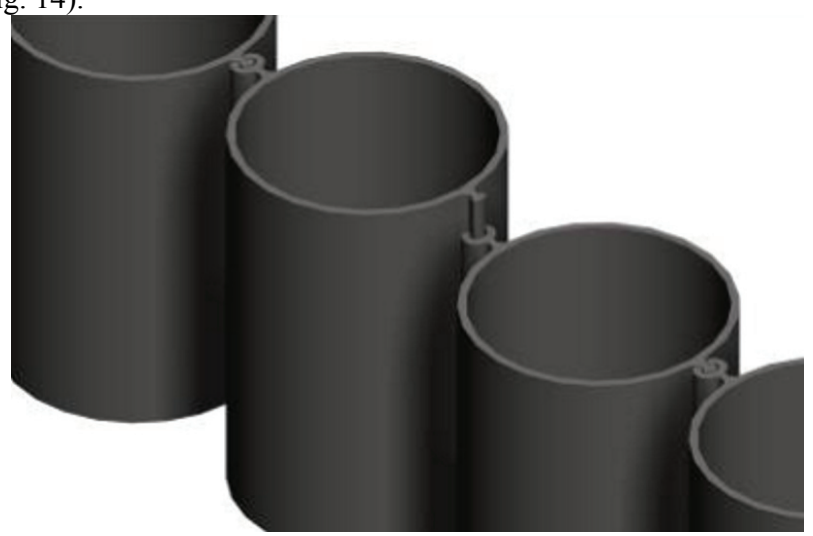

Fig. 14. Pipe clamping mechanism.

An example of using this technology is the construction of a tunnel in Trondheim, Norway. The construction of the tunnel was carried out in the old part of the city, with dense blockage of buildings built on wooden piles in muddy clay. To solve the problem of soil instability and prevent damage to old buildings, 360 piles were blocked with a blocking WoM / WoF (Fig. $15 \mathrm{a}, \mathrm{b})$.
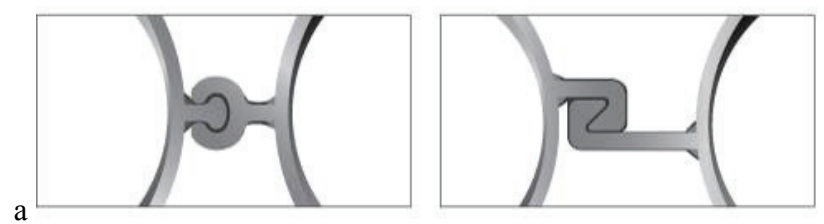

$\mathrm{b}$

Fig. 15. Types of lock elements of pile wall technology: a - lock type WoM/WoF; b - lock type C6. 

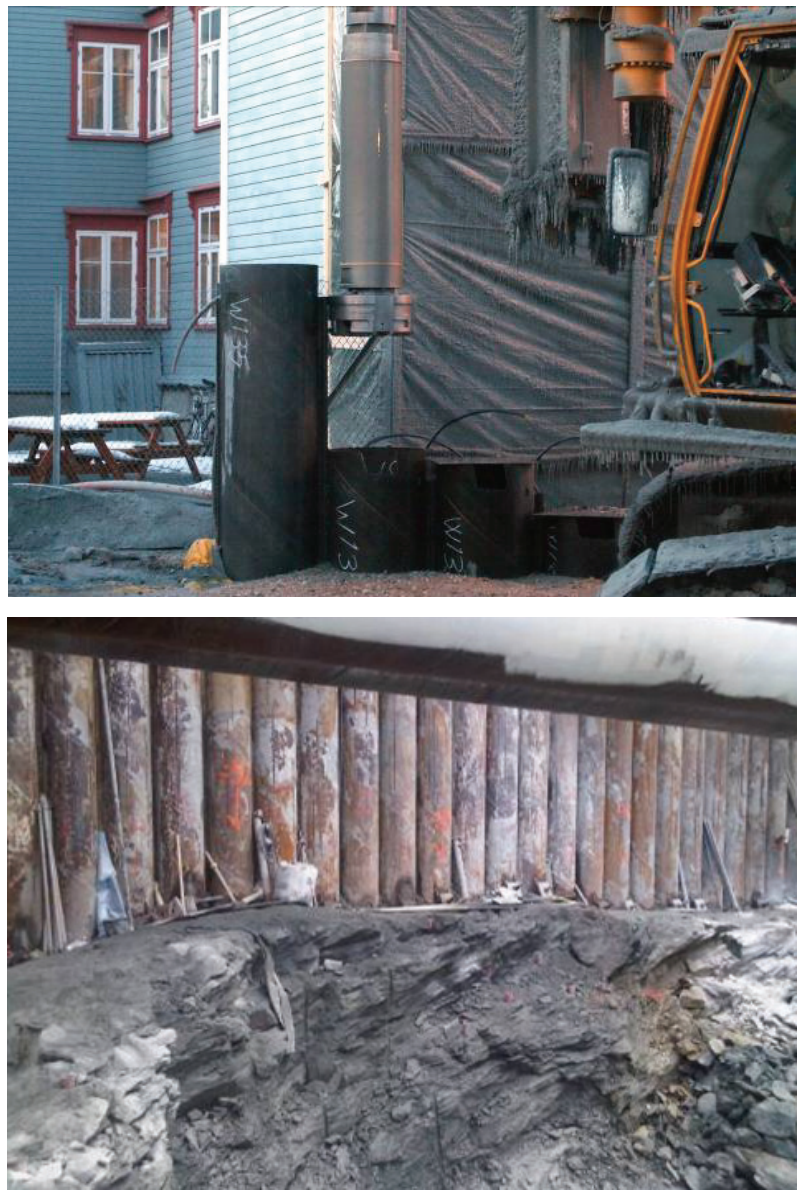

Fig. 16. Tunnel construction in Trondheim using pile wall technology.

\section{Conclusions}

1. For a rational development of the right-bank part of the city of Dnipro, an urgent task is the detailed mapping and analysis of the existing ravines and gullies.

2. To determine the stability and degree of landslide of the slopes, it is advisable to use the NIEMFE observation method, which allows to identify potentially landslide-prone slopes and areas that can be used in the urban infrastructure with low loads on the soil massif.

3. To determine the feasibility on which of the landslide-prone slopes can be applied considered technologies strengthen the boards.

\section{References}

1. Passport of the radio-wave indicator of the stress-strain state of the rocks (RVINDS AHI 2.026.001 PS). (1984). Lviv Plant of Geophysical Equipment

2. Tyapkin, K., Gontarenko, V. (1990). Sistemy razlomov Ukrainskogo shchita [Fault systems of the Ukrainian shield]. Kyiv: Naukova Dumka

3. Gursky, D.S, Kruglov, S.S. (2007). Tektonichna karta Ukrayiny [Tectonic map of 
Ukraine S 1: 1000000] Kyiv: State Geological Service, UkrDGRI

4. Zmiievska K. (2015). Sposib vyyavlennya rozryvnykh porushen u krystalichnykh porodakh. Patent No 99831, Ukraine

5. Bilyj I.S., Dovbnich, M.M., Kuzina, G.P., Stovas, G.M. (2004). Zvit pro vykonannya nazemnyh zavirochnyh sposterezhen pryrodnogo impulsnogo elektromagnitnogo polya Zemli (PIEMPZ) na ploshhi skhidnogo bortu Monastyrskoyi balky $u$ m. Dnipropetrovsku. Ukrayinskyj derzhavnyj geologorozviduvalnyj instytut, tema \# 946-x

6. Atlas Copco Geotechnical Engineering Products (Sweden. Marsta. № 69911799 01, 1131, 2013)

7. Atlas Copco Rock Reinforcement Products (Sweden. Marsta. № 69911571 13b, 2009)

8. Atlas Copco Ground Engineering Products (Sweden. Marsta. № 69911570 13b, 1-63, 2009) 